\title{
Restoration of Cirsio-Molinietum wet meadows by sod cutting 1
}

\author{
André J.M. Jansen ${ }^{\mathrm{a},{ }^{*}}$, Jan G.M. Roelofs ${ }^{\mathrm{b}}$ \\ ${ }^{a}$ Kiwa NV, Research and Consultancy, P.O. Box 1072, 3430 BB Nieuwegein, The Netherlands \\ ${ }^{\mathrm{b}}$ Department of Ecology, Research group Environmental Biology, Unicersity of Nijmegen. \\ Toernooiveld, 6525 ED Nijmegen, The Netherlands
}

Received 21 May 1995; revised 15 February 1996; accepted 12 August 1996

\begin{abstract}
This study evaluates the prospects for restoration of the Cirsio-Molinietum orchietosum by sod cutting of an eutrophicated Cirsio-Molinietum stand and of a former agricultural grassland and an alder carr, respectively. Sod cutting of the former agricultural grassland and of the alder carr sufficed to restore this plant community, whereas sod cutting of the eutrophicated Cirsio-Molinietum was not successful. The unsuccessful restoration of the eutrophicated Cirsio-Molinietum might be due to prolonged inundation resulting from the sod cutting, causing anaerobic conditions under which no nitrification takes place. The chemical composition of the deep groundwater supplying the site changed from base-rich and $\mathrm{SO}_{4}^{2-}$-poor to base-rich and $\mathrm{SO}_{4}^{2-}$-rich. This change in chemical composition of the deep groundwater, discharging in the study area, might cause a higher nutrient availability in the root zone, and therefore, negatively influence the prospects for the restoration of the Cirsio-Molinietum. Furthermore, successful restoration of the CirsioMolinietum requires (1) water tables close to the soil surface during at least six months and (2) discharging base-rich groundwater in the root zone.
\end{abstract}

Keywords: Agricultural grassland; Alder carr; Anaerobic conditions; Sulphate-rich groundwater; Prolonged inundation; Phosphorus release; Groundwater tables

\section{Introduction}

The Cirsio-Molinietum (alliance Junco-Molinion) is a plant community of wet meadows on slightly acid to neutral soils with a low nutrient availability (Jansen and Maas, 1993; Westhoff and Den Held, 1969).

\footnotetext{
* Corresponding author. Tel.: (31-30) 606-9585; Fax: (31-30) 606-1165.

'Presented at the workshop "Ecologcal engineering for ecosystem restoration", 28-30 November 1994, Zeist. The Netherlands.
} 
Until the beginning of this century, the Cirsio-Molinietum was widespread in the Netherlands. However, as a result of land reclamation. increased fertilization and changes in the water management only 30 ha remain of the original area of several tens of thousands of hectares (Schaminée, 1993). Consequently, the Cirsio-Molinietum is one of the most endangered mesotrophic plant communities, not only in the Netherlands but also elsewhere in its distribution area - northwestern Europe (Buck-Sorlin. 1993: Schaminée, 1993; Rodwell, 1991).

Moreover, the last remaining Cirsio-Molinietum orchietosum stands are severely endangered by acidification and eutrophication as a result of (1) lowering of the groundwater table, (2) increasing acid and (3) nitrogen deposition from the atmosphere and (4) (indirectly) impact of excessive fertilization (Rodwell, 1991; Schaminée, 1993; Westhoff and Den Held, 1969; De Graaf et al., 1994). These changes cause severe eutrophication.

As a result of acidification and eutrophication, the low-productive Cirsio-Molinietum is replaced by a vegetation of usually high-productive species. such as the vascular plants Calamagrostis canescens, Filipendula ulmaria and Carex disticha, and the bryophyte Calliergonella cuspidata. Therefore, the restoration of this severely endangered community is urgent from a nature conservation point of view.

The present paper deals with the Lemselermaten, a nature reserve in the Twente region, eastern Netherlands, which was known for its well-developed Cirsio-Molinietum (Westhoff and Jansen, 1990) (Fig. 1). Although the nature reserve has never been fertilized and is still being mown every year, by 1990 most of the species of the Cirsio-Molinietum orchietosum, that were found in 1944, and some of them even until the 1960s and the 1970s (Kleuver, unpublished data), had disappeared (Westhoff and Jansen, 1990). The changes in species composition indicate:

(1) Declining groundwater tables during spring and summer, whereas water tables in winter remain high, as indicated by the expansion of Calamagrostis canescens (Soukupová, 1992);

(2) eutrophication of the top soil. Species that indicate nutrient-rich conditions have expanded, whereas species that indicate nutrient-poor conditions have disappeared or decreased.

Apparently, the deterioration of the Cirsio-Molinietum has not been prevented by the yearly hay-making. Therefore, other measures are necessary for restoring the CirsioMolinietum at the Lemselermaten, notably sod cutting. Through sod cutting the nutrient-rich top soil layer is removed, whereas the soil surface is lowered, causing nutrient-poor and wetter conditions for the vegetation. If indeed eutrophication would have caused the deterioration of the Cirsio-Molinietum at the Lemselermaten, but water tables would still be high enough, removal of the nutrient-rich top soil by sod cutting might restore the site conditions of the Cirsio-Molinietum. Therefore, part of the old nature reserve was sod cut (Figs. 1 and 2).

Contiguous to the nature reserve some hectares of agriculturally used, nutrient-rich grassland, are situated (Fig. 1). This grassland joins an alder carr, that is situated downslope (Fig. 1). The agricultural grassland and the alder carr are the new reserve. The old and new reserve have a comparable elevation and, presumably, comparable groundwater tables; both have a nutrient-rich top soil. Due to the soil and groundwater 


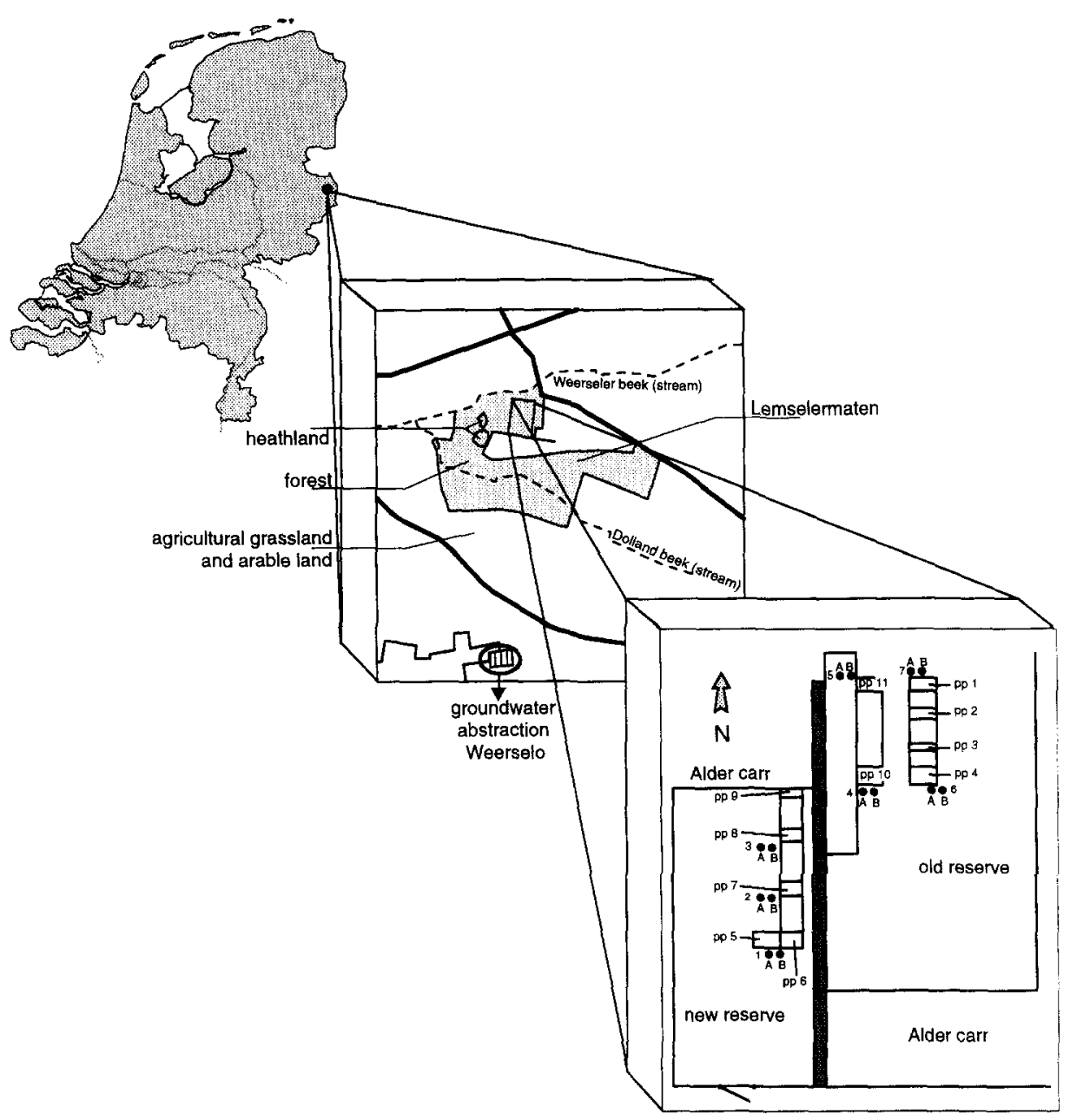

Fig. 1. Location of the study area in The Netherlands. $p p=$ permanent plot; black dots $=$ global position of piezometers; $\mathrm{A}=$ piezometer screened at $50 \mathrm{~cm}$ below the soil surface; $\mathrm{B}=$ piezometer $\mathrm{screened}$ at $150 \mathrm{~cm}$ below the soil surface. pp 1-4: in the untreated part of the old reserve: pp 10 and 11 : in the sod cut strip of the old reserve; pp 5-9: sod cut new nature reserve the Lemselermaten.

situation as well as the proximity of populations of several rare species, the possibilities for restoration of species-rich Cirsio-Molinietum seemed promising in the new reserve. Therefore, the nutrient-rich top soil of the grassland and alder carr was sod cut (Fig. 2). The alder carr was sod cut after the trees were removed.

In this paper we will (i) evaluate the perspectives for restoration of the CirsioMolinietum by sod cutting at the old and new nature reserve and (ii) determine the abiotic key-factors for successful restoration of the Cirsio-Molinietum. Therefore, groundwater tables and the chemical composition of soil, groundwater and surface water were measured at the sites where measures were taken. In this respect hydrological and 


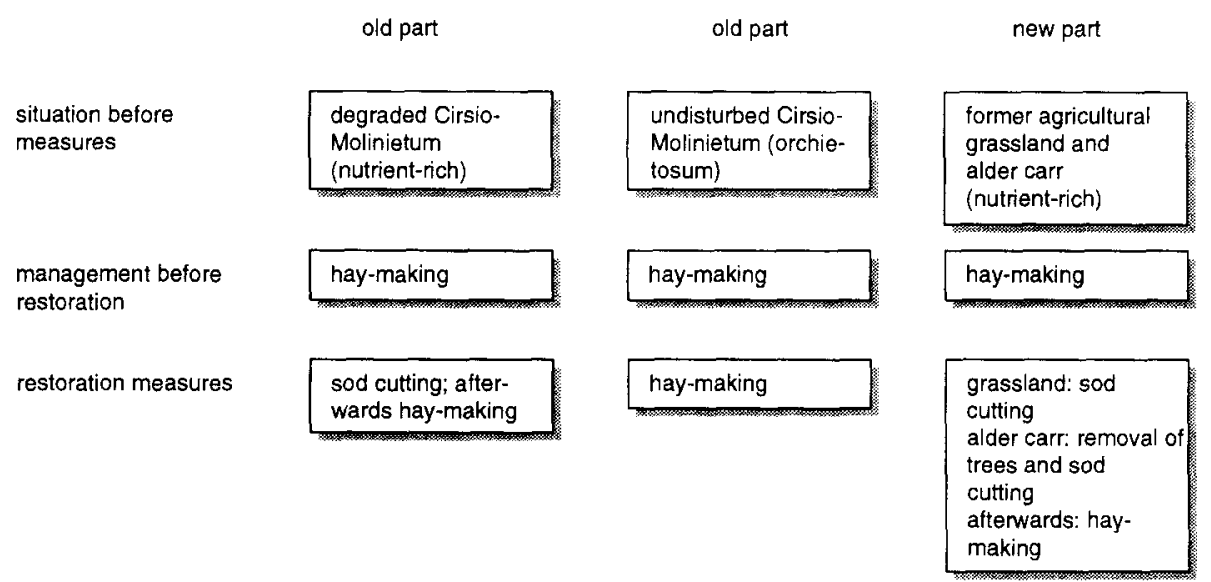

Fig. 2. Situation and management before restoration was carried out and restoration measures taken at the old and new part of the nature reserve the Lemselermaten.

hydrochemical relations of Cirsio-Molinietum sites with the surrounding landscape are of primary importance (Grootjans, 1985; Bakker et al., 1987; Boeye and Verheyen. 1994).

\section{Site description and restoration measures}

\subsection{Situation, land-use and restoration measures}

The study area is part of the Lemselermaten, a brook valley area in the eastern part of the Netherlands $\left(52^{\circ} 21^{\prime} \mathrm{N}, 6^{\circ} 53^{\prime} \mathrm{E}\right)$ (Fig. 1). Parts of this brook valley are protected as a nature reserve; they include alder carrs, wet hay-meadows and heathlands. The study area includes a wet meadow, which is the 'old' nature reserve, and the 'new' reserve, that consists of a former agricultural grassland and of a former alder carr.

The Lemselermaten is bound by two brooklets to the north and the south. The central part of the Lemselermaten consists of a ridge of wind-borne sand deposits that gradually slopes to the wet meadows and alder carrs, which are situated along the brooklets. In about 1960 these brooklets were canalized and deepened. Groundwater abstraction for drinking water purposes started in 1966 at $1 \mathrm{~km}$ south of the Lemselermaten. About 1950 the central part of the Lemselermaten consisted of heathlands; the lower parts of wet meadows, which were mown yearly. In the 1940s and 1950s most of the wet meadows were abandoned by the farmers and developed gradually into an alder carr. The central part of the Lemselermaten and some wet meadows were reclaimed, whereas two small heathlands and one wet meadow were protected as a nature reserve. This protected meadow is the old reserve and is being mown yearly.

Since 1980 the former agriculturally used grassland was subjected to restoration measures, i.e. mowing and hay-making. The alder carr downslope of this grassland has developed after 1950, after the wet meadows were abandoned. In 1989 the lower parts 
of the this grassland were sod cut $(5-15 \mathrm{~cm})$, whereas the alder carr was removed and sod cut (approximately $15 \mathrm{~cm}$ ). Sods were cut down to the mineral soil. From one year after sod cutting the vegetation has been mown yearly.

In the old reserve, a strip dominated by Filipendula ulmaria and Calamagrostis canescens, was sod cut during the winter of 1991. The remaining part of the old reserve was mown annually as usual.

\subsection{Vegetation}

In 1944 the larger part of the wet meadows was covered by the Cirsio-Molinietum orchietosum (Westhoff and Jansen, 1990). The Cirsio-Molinietum is characterized mainly by Molinia caerulea, Juncus conglomeratus, Gentiana pneumonanthe, Succisa pratensis, Viola stagnina, Carex panicea, Carex pulicaris, Carex hostiana and Cirsium dissectum (Westhoff and Den Held, 1969). Westhoff and Den Held (1969) distinguished the subassociation 'orchietosum', which is characterized by the phanerogams Gymnadenia conopsea, Epipactis palustris, Dactylorhiza incarnata, Parnassia palustris, Eriophorum latifolium and Pinguicula vulgaris, and accompanied by bryophytes such as Scorpidium scorpioides, Campylium stellatum and Fissidens adianthoides. This subassociation forms a floristic transition to the Caricion davallianae-alliance, known from base-rich mires, and is limited to sites with discharging base-rich groundwater (Westhoff and Den Held, 1969). Nowadays, this subassociation is restricted in the Netherlands to seven nature reserves.

At the lowest part a Scorpidio-Caricetum diandrae (alliance Caricion davallianae), a community characteristic of base-rich, nutrient-poor peatlands (Westhoff and Den Held, 1969; Kooijman and Bakker, 1995), was found (Westhoff and Jansen, 1990).

At present, the vegetation of the old nature reserve consists of three plant communities (Croese, 1993):

(1) At the lowest parts a Filipendulion, consisting of swards of Calamagrostis canescens and Filipendula ulmaria with Caltha palustris and Menyanthes trifoliata;

(2) at the highest parts the Cirsio-Molinietum typicum, characterized by Carex panicea, Carex pulicaris, Carex hostiana and Valeriana dioica;

(3) in between the Cirsio-Molinietum orchietosum, characterized by Dactylorhiza incarnata and Eriophorum latifolium. Of course, also the characteristic species of the Cirsio-Molinietum are present.

Before sod cutting, and after nine years of hay-making, the grassland in the new reserve still consisted of a highly productive vegetation, dominated by Holcus lanatus and Elymus repens. Before sod cutting Fraxinus excelsior, Salix pentandra and Carex elongata occurred in the alder carr. These species point to base-rich conditions.

\section{Methods}

\subsection{Vegetation}

Three transects were laid out, one in the sod cut new reserve and two in the old reserve (Fig. 1). In the old reserve one transect was laid out in the sod cut strip and the 
other one in untouched part, representing the Cirsio-Molinietum orchietosum. Within the transects several permanent plots of $4 \mathrm{~m}^{2}$ were laid out to follow the development of the vegetation (Fig. 1). The vegetation of the permanent plots was surveyed each year in July or August. Cover/abundance values of the species were estimated according to Londo (1975) and transformed to percentages according to Van Diggelen et al. (1990).

\subsection{Ground and surface water analysis}

Two piezometers, supplied with a cap and screened at $50 \mathrm{~cm}$ and at $150 \mathrm{~cm}$ below the soil surface, respectively, were placed at the corner of some permanent plots (Fig. 1). One piezometer, screened at $2 \mathrm{~m}$ below the soil surface, was placed in the ridge south of the reserve.

Water tables were measured twice a month at days 14 and 28. These data were combined in the form of duration lines, in which the time (in \% of the total time) is depicted that a certain groundwater level (in cm's below surface) is exceeded during a year.

On 9 april $1992 \mathrm{pH}$ of the surface water was measured at the inundated parts with a Conducta PM $9 \mathrm{pH}$ meter. In order to measure the chemical composition of ground and surface water, ground and surface watersamples were collected in April 1992 and in July 1993 only groundwater was sampled. The piezometers were pumped before sampling until $\mathrm{EC}_{25}$ had stabilized. Two $250 \mathrm{ml}$ samples per filter were taken and stored in brown glass bottles without inclusion of air. $\mathrm{pH}, \mathrm{EC}$ at $25^{\circ} \mathrm{C}\left(\mathrm{EC}_{25}\right)$ and $\mathrm{HCO}_{3}^{-}$were measured in the laboratory the same day, after which the samples were frozen at $-20^{\circ} \mathrm{C}$. Within two days $\mathrm{SO}_{4}^{2-}$ and $\mathrm{Cl}^{-}$were measured. Cations $\left(\mathrm{Ca}^{2+}, \mathrm{Mg}^{2+}, \mathrm{Na}^{+}\right.$and $\left.\mathrm{K}^{+}\right)$were measured after addition of $1 \mathrm{ml}$ of $\mathrm{HNO}_{3}$ to $250 \mathrm{ml}$ of water sample, using AAS (Houba et al., 1989). Anions $\left(\mathrm{HCO}_{3}^{-}, \mathrm{SO}_{4}^{2-}\right.$ and $\left.\mathrm{Cl}^{-}\right)$were measured spectrophotometrically.

In order to measure the chemical composition of deep groundwater at the groundwater pumping station Weerselo, samples were taken from four wells with screens at $30-45,30-48,31-53$ and 26-55 m below the soil surface in June 1993 and June 1994. This deep groundwater was analyzed in a similar way as the shallow groundwater at the Lemselermaten.

The reliability of the analyses was checked by calculating the ionic balance according to Stuyfzand (1993). Analyses with a deviation in the ionic balance of more than $10 \%$ from electro neutrality were discarded. We used two methods to depict the chemical composition of the ground and surface water: Stiff-diagrams (Stiff, 1951) and the MAION method by Van Wirdum (1991), based on the (dis)similarity between the samples and benchmark analyses for ground-, rain- and seawater.

\section{Results}

\subsection{Vegetation development after restoration}

In the new reserve a Cirsio-Molinietum community has developed within 5 years after sod cutting. Highly productive species have almost disappeared. In the old reserve 
the development of the vegetation has been very slow after sod cutting. Species of the Cirsio-Molinietum, as well as high productive species have remained rare or absent.

The first three years after sod cutting of the new reserve characteristic species of the alliance Nanocyperion, such as Carex oederi ssp. oederi, Juncus tenageia, Scirpus setaceus and Cicendia filiformis, were present. Species of this alliance are typical for the pioneer phases of the Cirsio-Molinietum, and occurred in the plots 5-7 (Fig. 1). The plots 5 and 6 are part of the former agricultural grassland, plot 7 of the former alder carr. Carex oederi ssp. oederi established in all sod cut plots. This species is decreasing in plots 7, 8 and 9 (new reserve, former alder carr), whereas it is increasing in plots 5,6 (new reserve, former agricultural grassland), 10 and 11 (old reserve).

Eleocharis quinqueflora and Pinguicula vulgaris, species characteristic of the early phase of the Cirsio-Molinietum orchietosum, established in the plots 7 and 8 (new reserve, former alder carr), which have an intermediate position in the transect.

Many species characteristic of the mature phase of the Cirsio-Molinietum, such as Carex pulicaris, Carex hostiana, Carex panicea, Carex flacca, Valeriana dioica, Molinia caerulea and Juncus conglomeratus have established within four years after sod cutting in the new reserve. These species are rarest in permanent plot 9 (former alder carr). Until now, characteristic species of the older phase of the subassociation 'orchietosum', such as Eriophorum latifolium and Dactylorhiza majalis do not occur in the new reserve.

In the new reserve highly productive species, such as Calamagrostis canescens and Filipendula ulmaria remained inconspicuous. In 1994, five years after sod cutting, they only reached a relatively high cover $(10-30 \%)$ in plot 9 (former alder carr).

Until now, species of the Cirsio-Molinietum did not appear in plots 10 and 11 at the sod cut strip in the old reserve. There, high productive species, like Calamagrostis canescens and Filipendula ulmaria have become rare.

In the old reserve where no sod cutting occurred high productive species, such as Filipendula ulmaria, still have remained dominant, especially in permanent plot 4 . Almost all species of the older phase of the Cirsio-Molinietum were present in plot 1 , but only some of them in plot 4 . Species of the subassociation 'orchietosum' were only present in plot 1 .

\subsection{Groundwater tables}

Fig. 3 shows the duration lines of 1992, 1993 and 1994. 1992 was a dry year. whereas 1993 and 1994 were wet years. The duration lines of the piezometers 4,5 and to a lesser extent 3 and 6 are characterized by prolonged inundation. At the other piezometers the highest groundwater tables reach the soil surface. In wet years, water tables around the soil surface occur during circa $80 \%$ of the year; in the dry year 1992 only during $50 \%$ of the year. In both dry and wet years the groundwater tables of piezometer 1 are lowest, whereas the groundwater tables of the other piezometers are more or less equal. With the exception of duration line 1, which refers to the elevated part of the transect, the water tables in the new reserve are comparable to those of the old reserve. 


\subsection{Chemical composition of ground and surface water}

In April 1992 the $\mathrm{pH}$ values of the surface water of inundated parts ranged between 6.5 and 8.2 .

The position of all water samples near point $\mathrm{G}$ in the MAION-diagrams indicates that the surfacewater and groundwater are very base-rich (Van Wirdum, 1991) (Fig. 4).
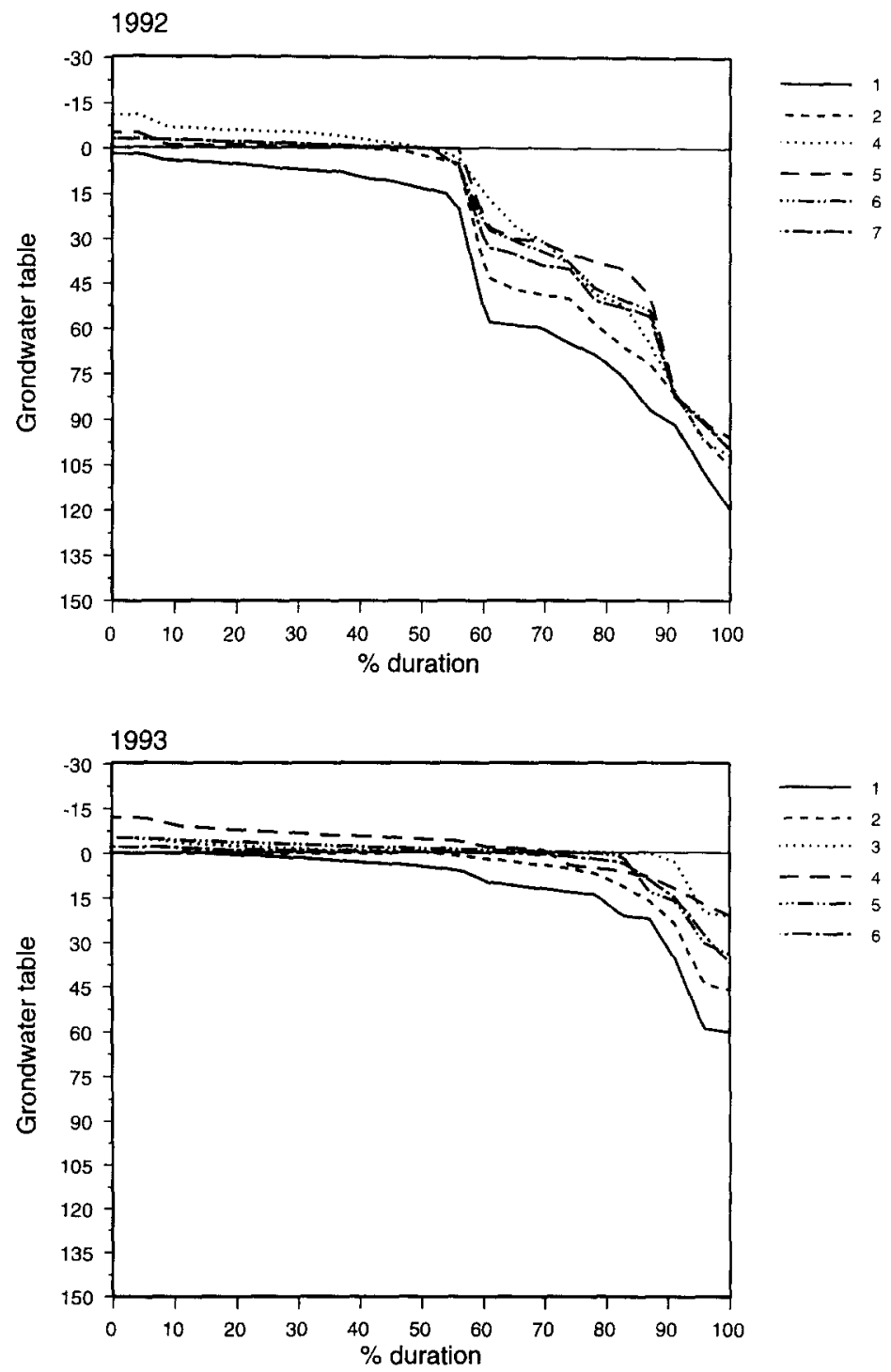

Fig. 3. Duration lines of piezometers in the Lemselermaten in 1992 (top panel, this page), 1993 (bottom panel. this page), 1994 (top panel, page 287), and 1993 and 1994 (bottom panel, page 287). Groundwater table in $\mathrm{cm}$ below soil surface. Numbers 1-3: sod cut new reserve; numbers 4 and 5: sod cut strip of the old reserve; numbers 6 and 7 : the untreated part of the old reserve (see also Fig. 1). 


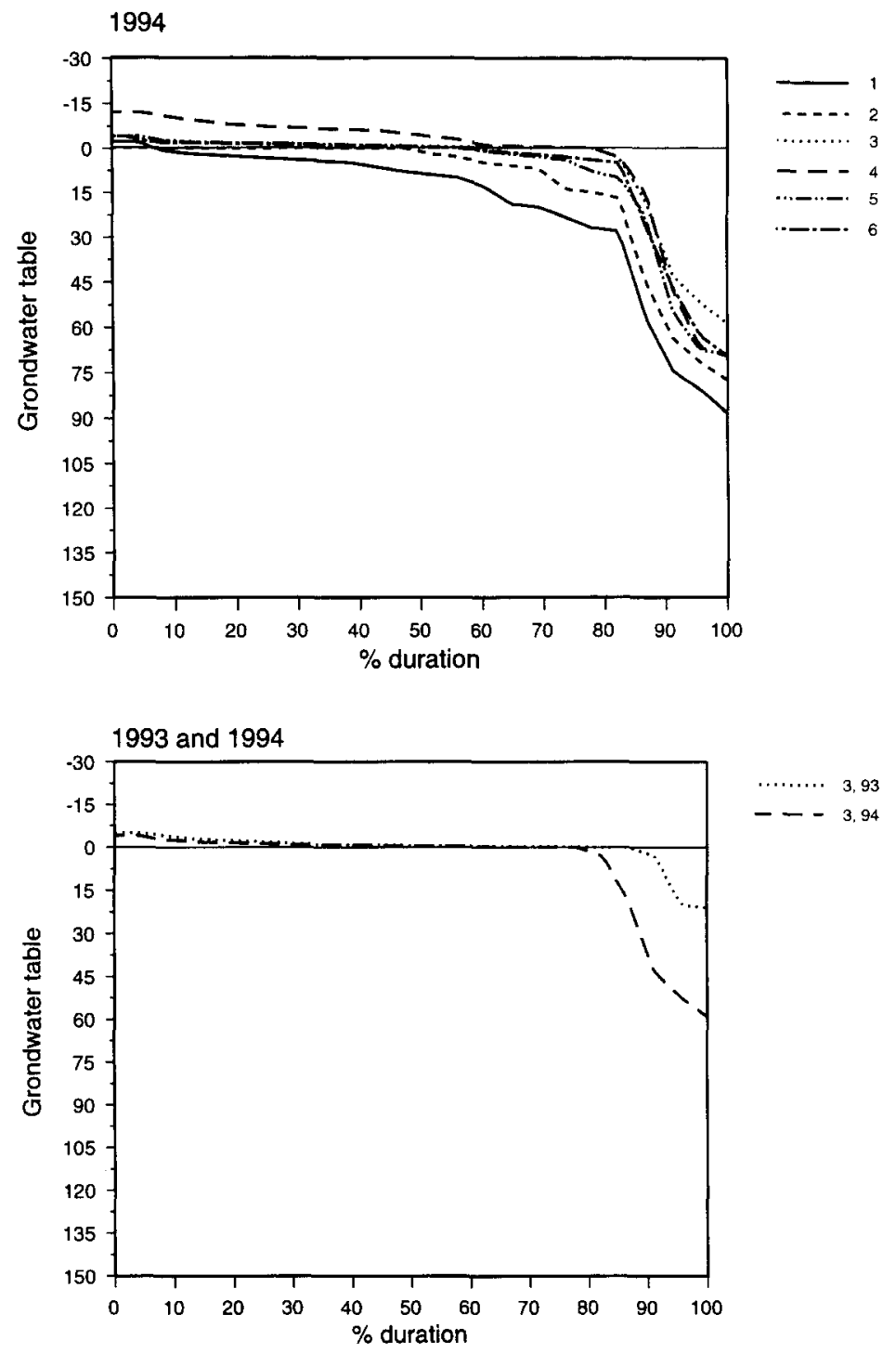

Fig. 3 (continued).

The cross-section shows a gradual transition in chemical composition of ground and surface water (Fig. 5). The water in the ridge and ditch can be classified as rainwater enriched in $\mathrm{Ca}^{2+}, \mathrm{SO}_{4}^{2-}$ and $\mathrm{Cl}^{-}$. At the lower part of the nature reserve ground and surface water-rich in $\mathrm{Ca}^{2+}$ and $\mathrm{HCO}_{3}^{-}$occurs, at some spots enriched with $\mathrm{SO}_{4}^{2-}$ and/or $\mathrm{Cl}^{-}$. The shallow groundwater and surface water have higher $\mathrm{Ca}^{2+}$ and $\mathrm{HCO}_{3}^{-}$, but mostly lower $\mathrm{SO}_{4}^{2-}$ and $\mathrm{Cl}^{-}$concentrations than the deep groundwater abstracted at Weerselo.

Table 1 shows the mean concentrations and standard deviations of $\mathrm{pH}, \mathrm{EC}$ (at $25^{\circ} \mathrm{C}$ ), 


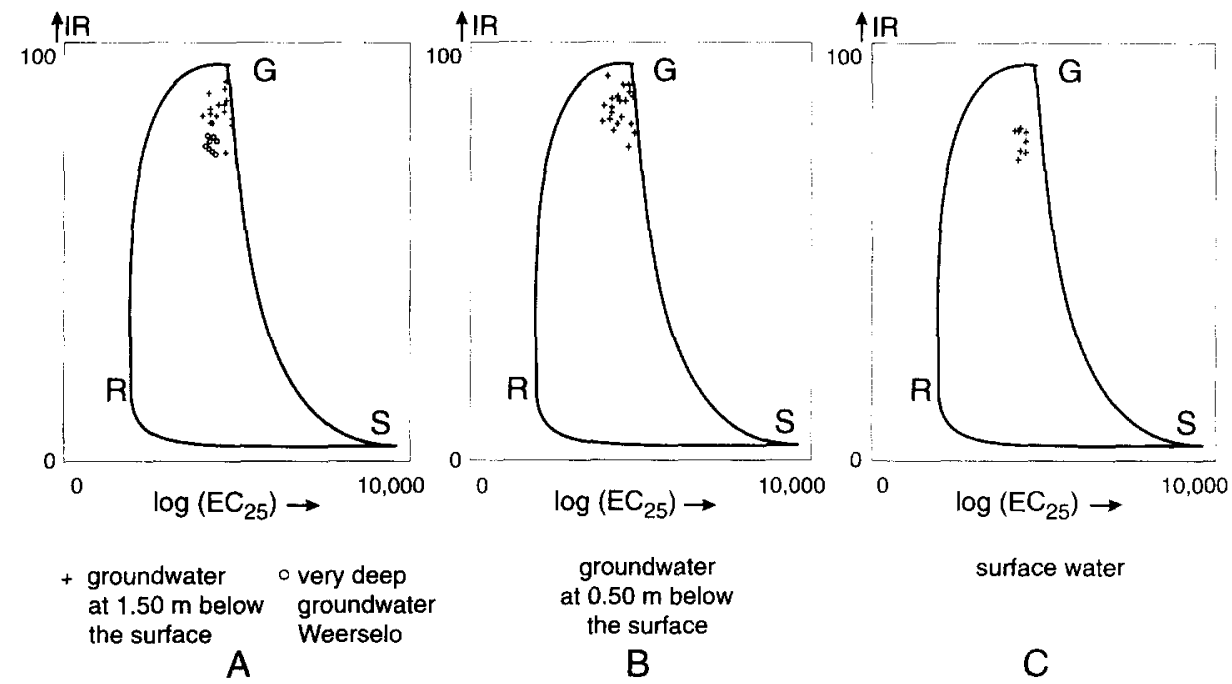

Fig. 4. MAION-diagram showing the position of water samples between the benchmark samples $\mathrm{G}=$ base-rich groundwater, $\mathrm{R}=$ rainwater and $\mathrm{S}=$ seawater. $\mathrm{IR}=$ ionic ratio, $\log (\mathrm{EC} 25)=\mathrm{EC}$ at $25^{\circ} \mathrm{C}$ on a logarithmic scale.

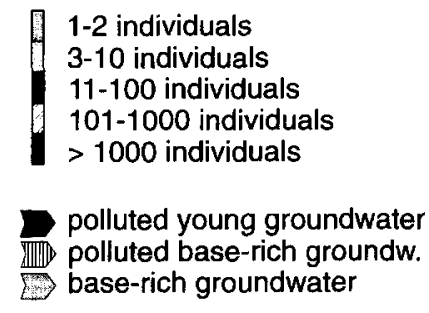

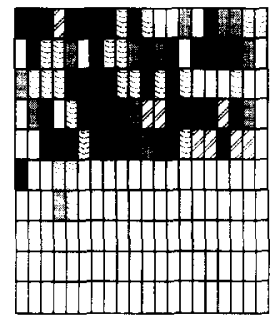
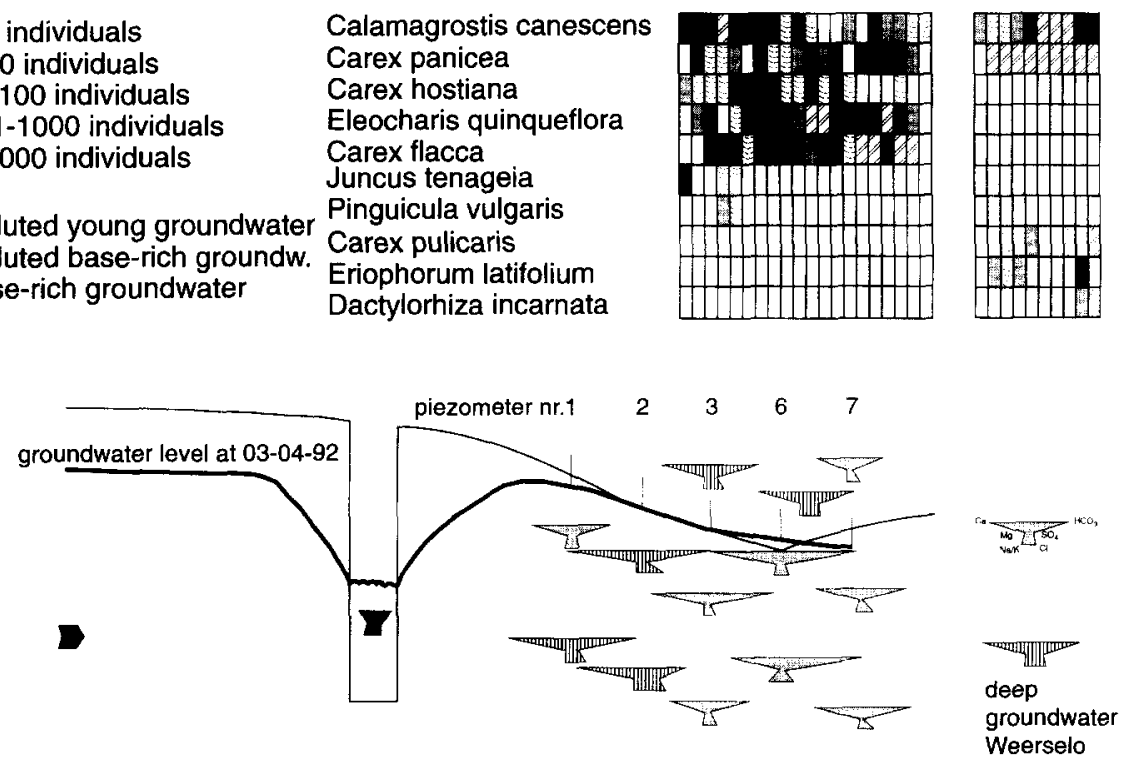

Fig. 5. Distribution of species and chemical composition of groundwater in 1992. The left grid shows the distribution of some species in the sod cut new reserve; the right grid that of the untreated part of the old reserve (see also Fig. 1). The piezometers $1-3$ are positioned in the new reserve; the piezometers 6 and 7 in the untreated part of the old reserve (see also Fig. 1). Concentrations of ions in the Stiff-diagrams are in $\mathrm{meq} / \mathrm{l}$. 
Table 1

Mean concentrations of $\mathrm{pH}$, Electric conductivity at $25^{\circ} \mathrm{C}\left(\mathrm{EC}_{25}\right), \mathrm{Cl}^{-}, \mathrm{SO}_{4}^{2-}$ and $\mathrm{HCO}_{3}^{-}$of the deep groundwater $(\mathrm{dg})$ abstracted at Weerselo and of the shallow groundwater at 0.5 and $1.5 \mathrm{~m}$ below the soil $\left(\mathrm{sg}_{0.5}\right.$ en $\mathrm{sg}_{1,5}$, respectively) and of the surface water ( $\mathrm{sw}$ ) at the Lemselermaten

\begin{tabular}{|c|c|c|c|c|}
\hline & $\begin{array}{l}\mathrm{dg} \text { Weerselo (1993 and 1994) } \\
n=8\end{array}$ & $\begin{array}{l}\mathrm{sg}_{0.5}(1992 \text { and } 1993) \\
n=14\end{array}$ & $\begin{array}{l}\mathrm{sg}_{1.5}(1992 \text { and } 1993) \\
n=10\end{array}$ & $\begin{array}{l}\text { sw }(9-4-992) \\
n=10\end{array}$ \\
\hline $\mathrm{pH}_{\mathrm{H}, \mathrm{O}}$ & $7.4 \quad(0.18)$ & $(0.19)$ & $(0.36)$ & $7.4 \quad(0.55)$ \\
\hline $\mathrm{EC}_{25}$ & $490.8(29.6)$ & $507.1(124.9)$ & $507.8(107.4)$ & $441 \quad(48.2)$ \\
\hline $\mathrm{Cl}^{-}$ & $42.1 \quad(4.1)$ & $29.4 \quad(13.8)$ & $34.3 \quad(14.6)$ & $40.4 \quad(7.3)$ \\
\hline $\mathrm{SO}_{4}^{2-}$ & $40.4(12.5)$ & $(14.0)$ & $14.5 \quad(24.3)$ & $15.1 \quad(13.1)$ \\
\hline $\mathrm{HCO}_{3}^{-}$ & $193.3 \quad(5.1)$ & $(77.6)$ & $299.9 \quad(69.8)$ & $239.1(58.1)$ \\
\hline
\end{tabular}

Concentrations in $\mathrm{mg} / \mathrm{l} ; \mathrm{EC}_{25}$ in $\mu \mathrm{S} / \mathrm{cm}$ (standard deviations added in parentheses).

$\mathrm{Cl}^{-}, \mathrm{SO}_{4}^{2-}$ and $\mathrm{HCO}_{3}^{-}$of the deep groundwater abstracted at Weerselo and those of the shallow groundwater and the surface water at the Lemselermaten. The mean $\mathrm{pH}$ of the deep groundwater is equal to or higher than that of the shallow groundwater and surface water. The mean value of the $\mathrm{EC}$ is more or less equal to that of the shallow groundwater, but somewhat higher than that of the surface water. The mean value of $\mathrm{Cl}^{-}$of the deep groundwater is higher than those of the shallow groundwater and the surface water. The mean $\mathrm{HCO}_{3}^{-}$concentrations of the shallow ground and surface water always exceed that of the deep groundwater, whereas the mean $\mathrm{SO}_{4}^{2-}$ concentrations of the shallow groundwater and surface water are lower than that of the deep groundwater. The mean $\mathrm{SO}_{4}^{2-}$ concentration of the shallow groundwater at $0.50 \mathrm{~m}$ below the soil surface is somewhat lower than that of the groundwater at $1.50 \mathrm{~m}$ below the soil surface (Table 1).

Table 2 shows the mean concentrations and standard deviations of $\mathrm{pH}, \mathrm{Cl}^{-}, \mathrm{SO}_{4}^{2-}$ and $\mathrm{HCO}_{3}^{-}$of the shallow groundwater and the surface water along the three transects. In the transects there neither exist clear differences in mean $\mathrm{pH}$ of the shallow groundwater, nor in mean $\mathrm{pH}$ of the surface water. In the old reserve the mean $\mathrm{Cl}^{-}$ concentration of the shallow groundwater is similar in both transects, but lower than that of the new reserve. The mean $\mathrm{Cl}^{-}$concentrations of the surface water are more or less equal. In the sod cut strip of the old reserve the mean $\mathrm{SO}_{4}^{2-}$ concentration of the shallow groundwater at $0.5 \mathrm{~m}$ below the soil surface is close to zero, whereas it is much higher in both other transects. The mean $\mathrm{SO}_{4}^{2-}$ concentrations of the shallow groundwater at $1.5 \mathrm{~m}$ below the soil surface are higher than those of the shallow groundwater at $0.5 \mathrm{~m}$ below the soil surface. The mean $\mathrm{SO}_{4}^{2-}$ concentrations of the surface water are more or less the same. In the sod cut part of the old reserve the mean $\mathrm{HCO}_{3}^{-}$concentration of the shallow groundwater at $0.5 \mathrm{~m}$ below the soil surface is highest, while that in the new reserve is lowest. The mean $\mathrm{HCO}_{3}^{-}$concentrations of the shallow groundwater at $0.5 \mathrm{~m}$ below the soil surface exceed those of the shallow groundwater at $1.5 \mathrm{~m}$ below the soil surface. The mean $\mathrm{HCO}_{3}^{-}$concentrations of the surface water do not differ very much. In any transect the mean $\mathrm{pH}$ and the mean $\mathrm{Cl}^{-}$and $\mathrm{SO}_{4}^{2-}$ concentrations of the surface water almost always exceed those of the shallow groundwater. The opposite applies to the mean $\mathrm{HCO}_{3}^{-}$concentrations.

In the inundated parts the mean $\mathrm{Cl}^{-}$and $\mathrm{SO}_{4}^{2-}$ concentrations of the shallow 


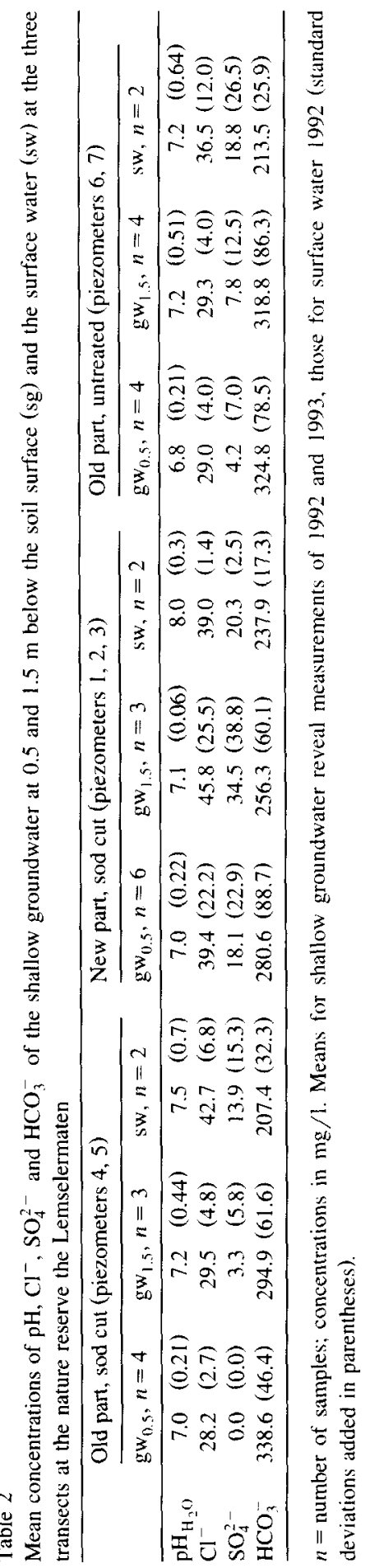


Table 3

Mean concentrations of $\mathrm{pH}, \mathrm{Cl}^{-}, \mathrm{SO}_{4}^{2-}$ and $\mathrm{HCO}_{3}^{-}$of the shallow groundwater at $0.5 \mathrm{~m}\left(\mathrm{sg}_{0.5}\right)$ and $1.5 \mathrm{~m}$ $\left(\mathrm{sg}_{1.5}\right)$ below the soil surface and the surface water $(\mathrm{sw})$ at inundated and not inundated parts at the nature reserve the Lemselermaten

\begin{tabular}{|c|c|c|c|c|}
\hline \multirow[b]{3}{*}{$\widehat{\mathrm{pH}_{\mathrm{H}, \mathrm{O}}}$} & \multicolumn{2}{|c|}{ Inundated (piezometers $3,4,5,6$ ) } & \multicolumn{2}{|c|}{ Not inundated (piezometers $1,2,7$ ) } \\
\hline & $\mathrm{sg}_{0.5}, n=8$ & $\operatorname{sg}_{1.5}, n=6$ & $s g_{0.5}, n=6$ & $\mathrm{sg}_{1.5}, n=4$ \\
\hline & $7.0 \quad(0.21)$ & $7.1 \quad(0.32)$ & $6.9(0.19)$ & $7.2 \quad(0.46)$ \\
\hline $\mathrm{Cl}^{-}$ & $25.4 \quad(3.8)$ & $27.4 \quad(4.1)$ & $34.7(20.4)$ & $44.6(19.4)$ \\
\hline $\mathrm{SO}^{2-}$ & $0.25 \quad(0.71)$ & $2.7 \quad(4.1)$ & $18.4(16.9)$ & $32.2(32.3)$ \\
\hline $\mathrm{HCO}_{3}^{-}$ & $328.7 \quad(79.8)$ & $313.2(80.9)$ & $262.3(60.7)$ & $262.3(40.8)$ \\
\hline
\end{tabular}

$n=$ number of samples; concentrations in mg/l. Means for shallow groundwater reveal measurements of 1992 and 1993 (standard deviations added in parentheses).

groundwater are lower than those of the non-inundated parts (Table 3). The mean $\mathrm{HCO}_{3}^{-}$concentrations show the opposite trend.

\section{Discussion}

\subsection{Restoration of the new reserve}

In the new nature reserve, which before sod cutting consisted of a former agricultural grassland and an alder carr, the prospects for the restoration of the Cirsio-Molinietum by sod cutting are promising. Both species of the younger and older phase of the Cirsio-Molinietum have returned, whereas highly productive species have not become abundant until now. In the new reserve, species of the younger phase of the sub-community 'orchietosum' have returned in the former alder carr, but not in the former agricultural grassland. The quick reappearance of many species of both the younger and older phase of the Cirsio-Molinietum within five years after sod cutting was unexpected. With the exception of Carex species, many characteristic species of this community have a (very) short-lived seed bank (Maas and Schopp-Guth, 1995). Our results show that most of the characteristic species of the Cirsio-Molinietum were present in the seed bank or could disperse easily from the neighbouring old reserve.

Species characteristic of the older phase of the Cirsio-Molinietum orchietosum, i.e. Eriophorum latifolium and Dactylorhiza incarnata, have not returned, although they occur in the contiguous old reserve. This might be due to:

(1) A slow seed dispersal;

(2) the low age of the humus profile. Within humus profiles of low age vertical gradients in chemical and physical properties are absent. Emmer (1995) showed that vertical differentiation within a developing humus profile may be pivotal for succession of undergrowth vegetation in pine forest. It is conceivable that this process, which could take some decades, might also be of importance for species of the Cirsio-Molinietum orchietosum;

(3) the absence of the required site conditions. The water tables are comparable to those of the untouched part of the old reserve, where these species still occur (Fig. 3). In 
both the new reserve and the untouched part of the old reserve very base-rich shallow groundwater is present (Fig. 5). Hence, both groundwater tables and the basic ion content of the shallow groundwater in the new reserve seem to be appropriate for species of the older phase of the Cirsio-Molinietum orchietosum.

\subsection{Restoration of the old reserve}

The sod cut strip in the old reserve is characterized by prolonged inundation as a consequence of sod cutting (Fig. 3, piezometers 4 and 5). By sod cutting the soil surface of the sod cut strip has become lower than its vicinity. Water will, therefore, accumulate in this artificial depression during wet periods, resulting in prolonged inundation.

Four years after sod cutting no species of the Cirsio-Molinietum did establish in the old reserve. This might be due to frequent prolonged inundation after sod cutting. During prolonged inundation anaerobic or oxygen-poor conditions occur, under which most nitrogen is available as $\mathrm{NH}_{4}^{+}$(Haynes and Goh, 1978; Smolders and Roelofs, 1993). Many species of the Cirsio-Molinietum use $\mathrm{NO}_{3}^{-}$as a nitrogen source and can not survive $\mathrm{NH}_{4}^{+}$-rich conditions (Houdijk, 1993; De Graaf et al., 1994; De Graaf, 1994; Dijk and Eck, 1995). Therefore, anaerobic or oxygen-poor conditions, caused by prolonged inundation, might be responsible for the unsuccessful restoration of the Cirsio-Molinietum in the sod cut part of the old reserve.

\subsection{Discharge of groundwater}

The base-rich groundwater, which discharges into the nature reserve, originates from the deeper parts of the aquifer, because:

(1) The shapes of all duration lines point to the discharge of groundwater (Niemann, 1963; Grootjans, 1985) (Fig. 3);

(2) the impermeable base narrows near the Lemselermaten, whereas the hydrological conductivity of the aquifer reduces. Therefore a part of the groundwater discharges to the brooklets and to the soil of the nature reserve (Fig. 6). Since the brooklets have been deepened a larger part of the groundwater flows to these brooklets than in the former situation. Another part of the groundwater in the aquifer is drawn off by the groundwater abstraction Weerselo, which is situated at the same position in the hydrological system as the Lemselermaten;

(3) both the shallow groundwater at the Lemselermaten and the deep groundwater abstracted by the pumping station Weerselo show a high similarity to the benchmark sample of very base-rich groundwater (Fig. 4).

\subsection{Chemical composition of groundwater}

Nowadays, the deep groundwater abstracted at Weerselo is rich in $\mathrm{Cl}^{-}$and $\mathrm{SO}_{4}^{2}$, and relatively poor in $\mathrm{HCO}_{3}^{-}$(Table 1). Since 1967 the $\mathrm{Cl}^{-}$and $\mathrm{SO}_{4}^{2-}$ concentrations of the deep groundwater abstracted at Weerselo have increased (Fig. 7). This is a consequence of strongly increased manure spraying by farmers in the catchment area of the groundwater abstraction during that period (Van Beek et al., 1989) (Fig. 7). Hence, 


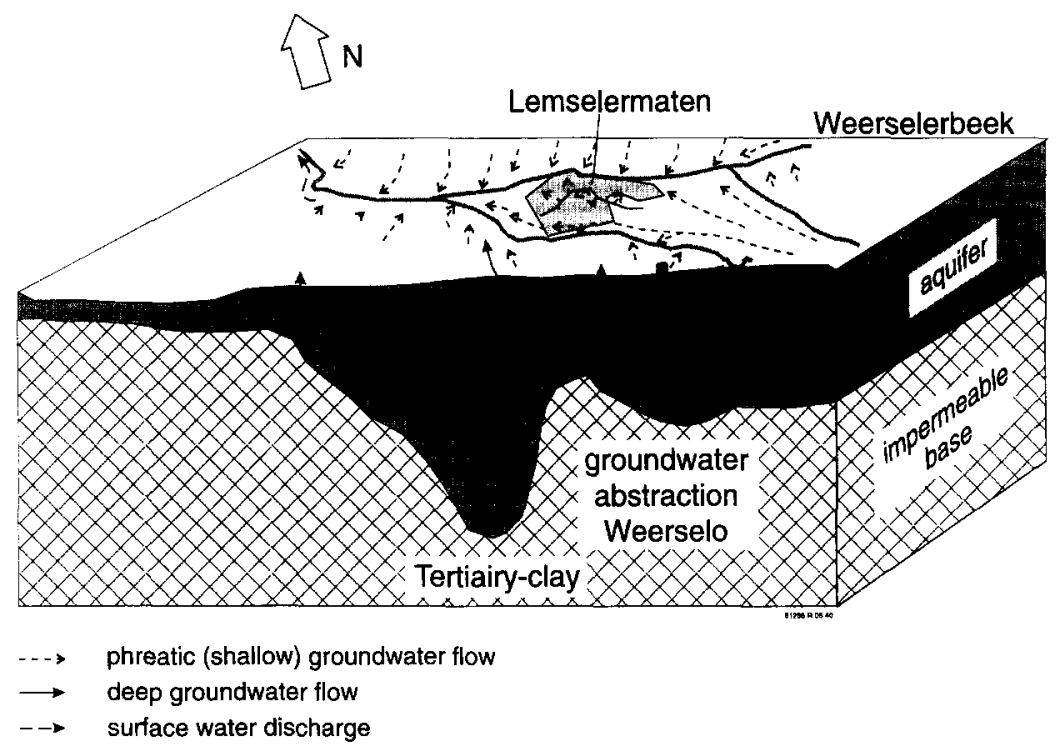

Fig. 6. Hydro-geology and schematic groundwater flow in the Lemselermaten and its surroundings.

the chemical composition of the deep groundwater has changed from $\mathrm{HCO}_{3}^{-}$-rich and $\mathrm{SO}_{4}^{2-}$ - and $\mathrm{Cl}^{-}$-poor to $\mathrm{HCO}_{3}^{-}$-rich and $\mathrm{SO}_{4}^{2-}$ - and $\mathrm{Cl}^{-}$-rich during the last decades.

Due to differences in groundwater tables, water flows also superficially from the agriculturally used ridge of wind-borne sand deposits to the nature reserve (Fig. 5). The Stiff-diagram and the relatively high $\mathrm{SO}_{4}^{2-}$ and $\mathrm{Cl}^{-}$concentrations of this water, indicate recently infiltrated rainwater, that is influenced by nutrient inputs from manure (Pedroli, 1989) (Fig. 5). Hence, the superficial flow of base-poor water from the nearby agricultural lots to the nature reserve might enhance the $\mathrm{Cl}^{-}$and $\mathrm{SO}_{4}^{2-}$ concentrations of the surface water in the nature reserve, especially in the old reserve (Tables 1 and 2).

\subsection{Consequences of changes in the groundwater composition}

The mean $\mathrm{HCO}_{3}^{-}$concentrations of the shallow ground and surface water bodies always exceed those of the deep groundwater at Weerselo (Tables 1 and 2). The mean $\mathrm{SO}_{4}^{2-}$ concentrations show the opposite. This points to the production of $\mathrm{HCO}_{3}^{-}$and the reduction of $\mathrm{SO}_{4}^{2-}$. These processes occur under anaerobic, non-acid conditions in the presence of organic material (Smolders and Roelofs, 1993). The overall equation of sulphate reduction is:

$$
\mathrm{SO}_{4}^{2-}+2 \mathrm{CH}_{2} \mathrm{O} \rightarrow \mathrm{HCO}_{3}^{-}+\mathrm{H}_{2} \mathrm{O}+\mathrm{HS}^{-}+\mathrm{CO}_{2} \text {. }
$$

The presence of $\mathrm{SO}_{4}^{2-}$-poor and $\mathrm{HCO}_{3}^{-}$-rich shallow groundwater can result from:

(1) The reduction of $\mathrm{SO}_{4}^{2-}$ in the aquifer (De Vries, 1969), resulting in the discharge of $\mathrm{SO}_{4}^{2-}$-poorer groundwater to the soil surface. The much lower mean $\mathrm{SO}_{4}^{2-}$ concentra- 

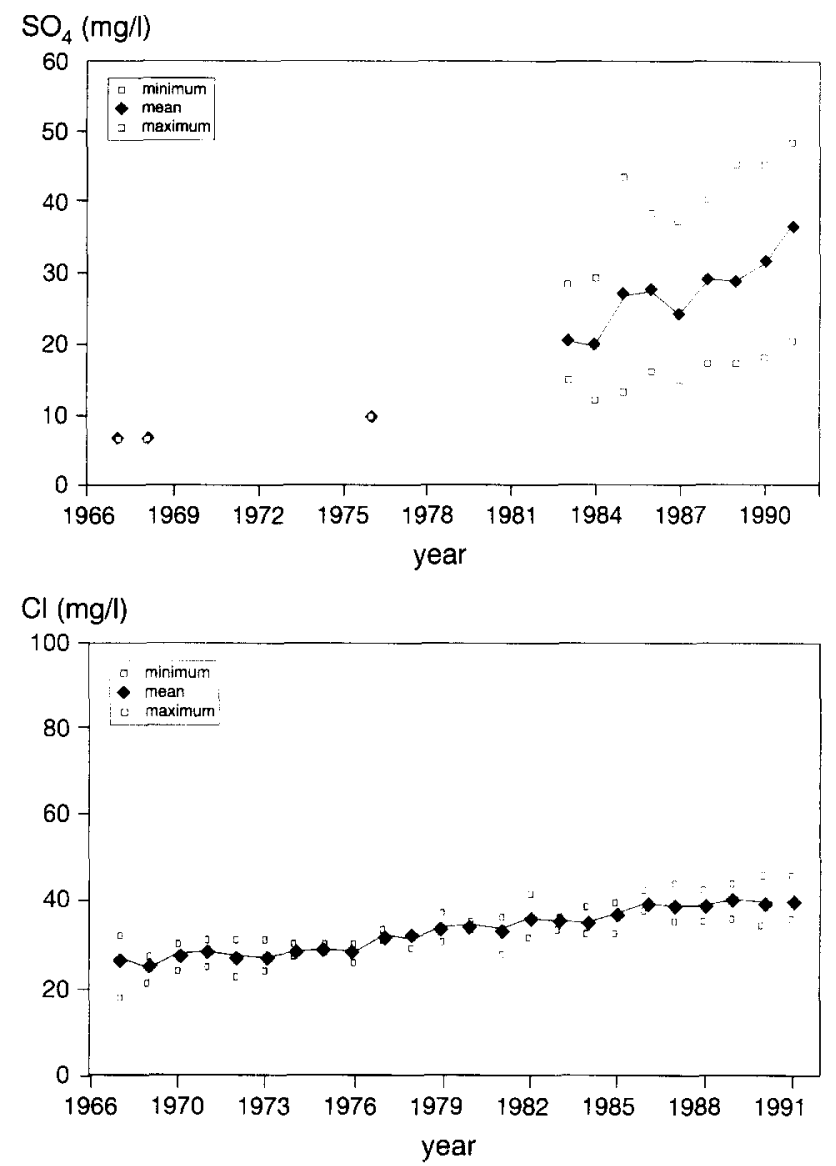

Fig. 7. Mean, minimum and maximum concentrations of $\mathrm{SO}_{4}^{2-}$ and $\mathrm{Cl}^{-}$of the deep groundwater abstracted at Weerselo from 1966-1991.

tion of the shallow groundwater at $1.50 \mathrm{~m}$ below the soil surface as compared to that of the deep groundwater at Weerselo underpins this hypothesis (Table I);

(2) prolonged inundation. The much lower mean $\mathrm{SO}_{4}^{2-}$ concentration and the higher mean $\mathrm{HCO}_{3}^{-}$concentration of the shallow groundwater of the inundated parts than those of the non-inundated parts point to the reduction of $\mathrm{SO}_{4}^{2-}$ and the production of $\mathrm{HCO}_{3}^{-}$ when prolonged inundation occurs (Table 3).

The supply of discharging $\mathrm{SO}_{4}^{2-}$-rich deep groundwater as well as the reduction of $\mathrm{SO}_{4}^{2-}$ and the formation of $\mathrm{HCO}_{3}^{-}$influence the nutrient availability in three ways:

(1) Caraco et al. (1989) show that high $\mathrm{SO}_{4}^{2-}$ concentrations of surface water also directly enhance the phosphate release of sediments;

(2) $\mathrm{S}^{2-}$ precipitates as FeS when the soil or the groundwater is iron-rich (Yoshida and Tadano, 1978; Giblin et al., 1990). In the soil a part of the iron is present as slightly soluble compounds, such as $\mathrm{FeO}(\mathrm{OH}), \mathrm{FeCO}_{3}$ and iron-phosphorous complexes. $\mathrm{FeS}$ precipitation and enhanced $\mathrm{Fe}^{3+}$ reduction by $\mathrm{S}^{2-}$ (Schindler, 1988) enhance the 
dissolution of such iron compounds. As a result of the dissolution of these iron complexes, the phosphate binding and sorbing capacity of the soil will decrease (Smolders and Roelofs, 1993);

(3) $\mathrm{High} \mathrm{HCO}_{3}^{-}$concentrations of the ground and surface water, which are present at the Lemselermaten (Table 1), cause better conditions for decomposition and mineralization of organic material and therefore for an increased nitrogen and phosphorus availability (Kok and Van de Laar, 1991). Whether or not these processes cause a higher availability of $\mathrm{N}$ and $\mathrm{P}$ to the vegetation of the Lemselermaten, requires further research.

Therefore, the changes in the chemical composition of the groundwater might have resulted in a much more productive vegetation and in the degradation of the former Cirsio-Molinietum at the old nature reserve. These changes might also negatively influence the long-term prospects for restoration of the Cirsio-Molinietum at the Lemselermaten. We doubt whether or not sod cutting of the new reserve results in restoration of the Cirsio-Molinietum on the long term, as long as they are fed by base-rich groundwater, that also is rich in $\mathrm{SO}_{4}^{2-}$. In the future a new organic top layer will arise, that will cause renewed eutrophication due to the constant supply of $\mathrm{SO}_{4}^{2--}$ and $\mathrm{HCO}_{3}^{-}$-rich water.

\subsection{Recommendations for nature management}

The Cirsio-Molinietum occurs at oligo-mesotrophic sites. Therefore, the restoration of this community requires nutrient-poor site conditions. Such conditions are maintained by high water tables and iron- and base-rich conditions, which are, therefore, key factors for the restoration of the Cirsio-Molinietum (Grootjans et al., 1986; Kemmers, 1986; Patrick and Khalid, 1974).

High water tables are water tables that reach the surface during at least circa $50 \%$ of a year and do not drop under $80 \mathrm{~cm}$ below the surface during a short period in summer. High water tables retard mineralization. In the sod cut strip in the old reserve prolonged inundation occurs. This should be avoided, because inundation with acid rainwater causes acidification, while inundation with base-rich water results in eutrophication of the Cirsio-Molinietum. Therefore, sod cutting should be carried out in such a way, that running off of rainwater and discharging groundwater over the soil surface can take place. This means, that sod cutting should follow slopes and must extend down to the lowest part of an area where stagnation takes place naturally or where an outlet occurs.

Seepage of iron-rich $(\mathrm{pH}<6.5)$ or $\mathrm{Ca}^{2+}$-rich $(\mathrm{pH}>6.5)$, but $\mathrm{SO}_{4}^{2-}$-poor groundwater is a necessity, too. It results in oligo-mesotrophic conditions by sorbing $\mathrm{P}$ (Patrick and Khalid, 1974). The supply of base-rich, but also $\mathrm{SO}_{4}^{2-}$-rich water, which causes alkalinization and eutrophication, must be prevented. This will be difficult, because it requires measures outside nature reserves, such as the reduction of manuring by farmers, or the purchase of buffer zones along nature reserves. When seepage of $\mathrm{Ca}^{2+}$ and iron-rich, but $\mathrm{SO}_{4}^{2-}$-poor water is absent, hydrological measures should be taken that reinforce the discharge of this water. When water tables and chemical composition of ground and surface water are suitable, sod cutting is a sufficient measure to restore the Cirsio-Molinietum due to the removal of nutrient-rich organic layers. The absence of 
thick organic top layers after sod cutting also restricts the influence of base-rich, but $\mathrm{SO}_{4}^{2-}$-rich water on the nutrient availability.

\section{Conclusions}

Sod cutting of the former agricultural grassland and of the alder carr sufficed to restore the Cirsio-Molinietum, whereas sod cutting of the eutrophicated Cirsio-Molinietum in the old reserve was not successful. This unsuccessful restoration might have been due to prolonged inundation, that occurred after sod cutting, causing anaerobic conditions under which no nitrification takes place. The eutrophication of the Cirsio-Molinietum at the old reserve might have been a result of the change in chemical composition of the deep groundwater, which supplies the site, from base-rich and $\mathrm{SO}_{4}^{2-}$-poor to base-rich and $\mathrm{SO}_{4}^{2-}$-rich. This change in chemical composition of the deep groundwater might have caused a higher nutrient availability in the root zone.

\section{Nomenclature}

Nomenclature of phanerogams is according to Van der Meijden (1990), that of bryophytes is according to Smith (1980) and that of syntaxa is according to Westhoff and Den Held (1969).

\section{Acknowledgements}

Our research was financed by the Ministry of Agriculture, Nature Conservation and Fishery. We want to acknowledge A.Th.W. Eysink (Staatsbosbeheer) for measuring the water tables and his important contribution to the research, T.H.M. Croese (Kiwa), B. van Delft (Staring Centrum), J. Jalink, M. de Graaf and W. Pik (Kiwa) for collecting data, and the Water Supply Company Overijssel for providing data. Comments on the manuscript by A.Th.W. Eysink, Prof. Dr. C. den Hartog, Dr. C. Maas, Prof. Dr. E. van der Maarel and the referees are gratefully acknowledged.

\section{References}

Bakker. J.P., Brouwer, C.. Van den Hof, L. and Jansen, A.J.M., 1987. Vegetational succession, management and hydrology in a brookland (the Netherlands). Acta Bot. Neerl.. 36: 39-58.

Boeye, D. and Verheyen, R.F., 1994. The relation between vegetation and soil chemistry gradients in a groundwater discharge fen. J. Veg. Sci., 5: 553-560.

Buck-Sorlin, G., 1993. Ausbreitung und Ruckgang der Enklischen Kratzdistel - Cirsium dissectum (L.) in Nordwestdeutschland. Tuexenia, 13: 183-191.

Caraco, N.F., Cole, J.J and Likens, G.E., 1989. Evidence for sulphate-controlled phosphorus release from sediments of aquatic systems. Nature, $341: 316-318$.

Croese, T.H.M., 1993, “Het Gammelke", vegetatie en landschapsecologie. Kiwa-report SWO 90.331. Kiwa N.V., Nieuwegein, the Netherlands. 
De Graaf, M.C.C., 1994. Ammonium and nitrate in heathland and heathland-related vegetations: preferences for nitrogen source and ammonium toxicity. Acta Bot. Neerl., 43: 393.

De Graaf, M.C.C., Verbeek, P.J.M., Cals, M.J.R. and Roelofs, J.G.M,, 1994. Effectgerichte maatregelen tegen verzuring en eutrofiëring van matig mineraalrijke heide en schraallanden. Eindrapport monitoringsprogramma eerste fase. Vakgroep Oecologie, Werkgroep Milieubiologie, University of Nijmegen, Nijmegen.

De Vries, J.J., 1969. Relatie tussen het sulfaat- en ijzergehalte in het diepe grondwater van de Gelderse Achterhoek. Water, 53: 623-627.

Dijk. E. and Eck, N.D., 1995. Ammonium toxicity and nitrate response of axenically grown Dactylorhiza incarnata (L.) Soó seedlings. New Phytol., in press.

Emmer, I.M., 1995. Humus form and soil development during a primary succession of monoculture Pinus sylvestris forests on poor sandy substrates. Thesis. University of Amsterdam, Amsterdam.

Giblin, A.E., Likens, G.E., White, D. and Howarth, R.W., 1990. Sulfur storage and alkalinity generation in New England lake sediments. Limnol. Oceanogr., 35: 852-869.

Grootjans, A.P., 1985. Changes of groundwater regime in wet meadows. Thesis. University of Groningen. Groningen.

Grootjans, A.P., Schipper, P.C. and Van der Windt, H.J., 1986. Influence of drainage on N-mineralization and vegetation response in wet meadows II. Cirsio-Molinietum stands. Acta Oecol./Oecol. Plant., $7: 3-14$.

Haynes, R.J. and Goh, K.M., 1978. Ammonium and nitrate nutrition of plants. Biol. Rev., 53: 465-510.

Houba, V.J.G., Van der Lee, J.J., Novozamsky, I. and Wallage, I., 1989. Soil and Plant Analysis. Part 5: Soil Analysis Procedures. Vakgroep Bodemkunde en Plantevoeding. Agricultural University of Wageningen, Wageningen.

Houdijk, A.L.F.M., 1993. Atmospheric ammonium deposition and the nutritional balance of terrestrial ecosystems. Thesis. University of Nijmegen, Nijmegen.

Jansen, A.J.M. and Maas, C., 1993. Ecohydrological processes in almost flat wetlands. Proceedings of the Symposium on Engineering Hydrology, San Fransisco, CA, 25-30 July 1993, pp, 150-155.

Kemmers, R.H.. 1986. Calcium as a hydrochemical characteristic for ecological states. Ekológica (CSSR). 5: $271-282$.

Kok, C.J. and Van de Laar, B.J., 1991. Influence of $\mathrm{pH}$ and buffering capacity on the decomposition of Nymphea alba L. detritus in laboratory experiments: a possible explanation for the inhibition of decomposition at low alkalinity. Verh. Int. Ver. Limnol., 24: 2689--2692.

Kooijman, A.M. and Bakker, C., 1995. Species replacement in the bryophyte layer in mires: The role of water type, nutrient supply and interspecific interactions. J. Ecol., 83: 1-8.

Londo, G., 1975. De decimale schaal voor vegetatiekundige opnamen van permanente ploten. Gorteria. 7: $102-106$.

Maas, D. and Schopp-Guth, A., 1995. Seed banks in fen areas and their potential use in restoration ecology. In: B.D. Wheeler, S.C. Shaw, W.J. Fojt and R.A. Robertson (Editors), Restoration of Temperate Wetlands. Wiley and Sons, Chichester.

Niemann, E., 1963. Beziehungen zwischen Vegetation und Grundwasser, ein Beitrag zur Präzisierung der ökologischen Zeigerwertes von Pflanzen und Pflanzengesellschaften. Arch. Naturschutz Landschaftsforsch.. 3: 3-37.

Patrick, Jr., W.H. and Khalid, R.A., 1974. Phosphate release and sorption by soils and sediments: effect of aerobic and anaerobic conditions. Science, 186: 53-55.

Pedroli, G.B.M., 1989. The nature of landscape. A contribution to landscape ecology and ecohydrology with examples from the Strijper Aa landscape, Eastern Brabant, The Netherlands. Thesis. University of Amsterdam, Amsterdam.

Rodwell, J., 1991. British plant communities, Vol. 2: Mires and Heaths. Cambridge University Press. Cambridge.

Schaminée, J.H.J., 1993. Het 'atlantische' blauwgrasland als plantengemeenschap: Teloorgang en behoud gedurende deze eeuw. In: E.J Weeda (Editor), Blauwgraslanden in Twente, schatkamers van het natuurbehoud. Wetenschappelijke Mededeling KNNV Nr. 209, Utrecht, pp. 15-3l.

Schindler. D.W., 1988. Confusion over the origin of alkalinity in lakes. Limnol. Oceanogr., 33: 1637-1640.

Smith, A.J.E., 1980. The moss flora of Britain and Ireland. Cambridge University Press, Cambridge.

Smolders, A. and Roelofs, J.G.M., 1993. Sulphate-mediated iron limitation and eutrophication in aquatic ecosystems, Aquat. Bot., 46: 247-253. 
Soukupová, L., 1992. Calamagrostis canescens: population biology of a clonal grass invading wetlands. Oikos, 63: 395-401.

Stiff Jr., H.A., 1951. The interpretation of chemical water analysis by means of patterns. J. Petrol. Tech., 3(10), Tech. Note 84, Sect. 1: 15-16, Sect. 2: 3 .

Stuyfzand, P.J., 1993. Hydrochemistry and hydrolgy of the coastal dune area of the western Netherlands. Thesis. Free University of Amsterdam, Amsterdam.

Van Beek, C.G.E.M., Hettinga, F.A.M. and Straatman. R.. 1989. The effects of manure spreading and acid deposition upon groundwater quality at Vierlingsbeek, the Netherlands. In: Proceedings of the Symposium held during the 3rd IAHS Scientific Assembly, Baltimore, MD. IAHS Publication No. 185. pp. 155-162.

Van der Meijden, R., 1990. Heukels flora van Nederland. Wolters-Noordhoff. Groningen.

Van Diggelen, R., Lubbers, G.W. and Van der Wal, J.T., 1990. VEGBASE version 3.0. Software Bureau for Ecological and Evolutionary Studies, Haren.

Van Wirdum, G., 1991. Vegetation and hydrology of floating rich-fens. Thesis. University of Amsterdam. Amsterdam.

Westhoff, V. and Den Held, A.J., 1969. Plantengemeenschappen in Nederland. Thieme, Zutphen.

Westhoff, V. and Jansen, A.I.M., 1990. Vegetatiegegevens uit de jaren veertig van Noordoost-Twente. Kiwa-report SWE 90.025, Nieuwegein.

Yoshida, S. and Tadano, T., 1978. Adaptation of plants to submerged soils. In: G.A. Jung (Editor), Crop Tolerance to Suboptimal and Conditions. American Society of Agriculture, Madison. WI, pp. 233-256. 